Сомбор

aleksandrauc@pef.uns.ac.rs

\title{
УПОТРЕБА СТРИПА У ОБРАДИ ИСТОРИЈСКИХ САДРЖАЈА У РАЗРЕДНОЈ НАСТАВИ
}

\begin{abstract}
АПСТРАКТ
Полазиште рада представљају ауторски ставови према којима настава у којој се усвајају историјски садржаји треба да афирмише активан приступ ученика и значајно повећање коришћења историјских извора. Подржавају се методичка разматрања према којима је за увођење ученика у комплексан проблем схаватања и тумачења далеке прошлости неопходна њихова замисао којом настоје да схвате и изразе шта значе и представљају историјски догађаји, појаве и процеси. Указује се да замисао о историјским збивањима успешно може подстаћи визуализација градива, те се решењем назначава синхронизовање текста и слике у облику стрипа. Дат је краћи преглед развоја стрипа и његове едукативне улоге, и истакнута могућност укључивања приче у сликама у наставу предмета Природа и друштво. У апликативном делу презентован је пример стрипа за наставну тему Знаменити људи нашег краја (трећи разред).
\end{abstract}

Кључне речи: стрип, историјски садржаји, настава природе и друштва.

\section{THE USE OF A COMIC BOOK IN PROCESSING HISTORICAL CONTENTS IN CLASSROOM TEACHING}

\begin{abstract}
The starting point of this paper are the author's attitudes according to which teaching of the historical resources needs to promote active approach of students and a significant increase in the use of historical sources. The paper supports the methodological considerations according
\end{abstract}


to which the introduction of students to the complex problem of understanding and interpretation of distant past requires them to understand and express the meaning of historical events, phenomena and processes. The paper indicates that the idea of historical events can be successfully encouraged through the visualization of material, by synchronization of text and images in the form of comics. The paper gives a brief overview of the development of comics and its educational role, and the possibility of including the stories featured in the pictures in the teaching of Nature and Society. In the applicative part, the possibilities of using a comic book in processing the topic for the lesson Famous people of our region (Nature and Society, third grade) have been presented.

Keywords: a comic, historical contents, teaching nature and society.

\section{1. УВОД}

Суштину мисаоног процеса у промишљању прошлости људског друштва представља анализа историјских процеса, појава и догађаја, али и личности које су их својом делатношћу обележиле. Неки аутори се опредељују за синтагму прошла стварност, сматрајући је полазиштем у тумачењу кључне одреднице: историја. Залажење у анализу прошле стварности значи мисаоно понирање у време које је давно иза нас. О њему морамо промишљати увек имајући на уму да постоји непрекинути ,ланац“ који повезује прошло, садашње и будуће: оно што је садашње постаје прошло, а оно што је будуће постаје временом садашње и потом прошло (Ђуровић 2010).

Ако проучавање историје сведемо само на прошлост, онда остајемо недоречени, и отежавамо развој историјске свести (као најважније компоненте друштвене свести) код ученика, што као практичну последицу има стварање празнина у ученичком знању и вештинама, које се већ на том узрасту морају изградити (Ђуровић 2010: 19). Дакле, да би се ученици могли уводити у комплексан проблем схаватања и тумачења историјских садржаја, потребно је прво да их подстакнемо да замишљају: потребна нам је њихова замисао којом настоје да схвате и изразе шта значе и представљају неки догађаји, појаве или процеси из прошлости.

Имајући у виду да су на млађем школском узрасту садржаји и активности ученика неодвојиви, таква замисао успешно би се могла подстаћи визуализацијом градива, односно синхронизовањем слике и текста у 
стриповној форми. Како деца наведеног узраста још нису овладала апстрактним мишљењем, визуално опажање за њих представља најнепосреднију и најупечатљивију комуникацију са наставним садржајима: „Захваљујући својој неупитној комуникацијској вриједности и могућности да сликовном нарацијом на једноставан и упечатљив начин износи поједине садржаје, медиј стрипа посебице је прикладан за обраду историјских тема“" (Lazzarich и Томљеновић 2011: 9). И поред тога што је едукативни потенцијал приче у сликама познат одавно, оскудна су разматрања која су усмерена на функционалну употребу стрипа у настави. Иако због комбинације сликовног и знаковног система порука стрип пружа многоструке предности, његова појава у школској пракси је сасвим спорадична - условљена афинитетима појединих учитеља који на плану индивидуалних напора укључују стрип у наставу.

У овом раду указујемо на значај стрипа, посебно апострофирајући његову едукативну улогу, и бавимо се промишљањем на који начин искрену дечју наклоност причама у слици и речи можемо искористити за ефикасно упознавање са историјским садржајима, како бисмо ученицима помогли да лакше обликују комплексну слику прошлости о којој уче у школи.

\section{2. ИСТОРИЈСКИ САДРЖАЈИ У РАЗРЕДНОЈ НАСТАВИ КАО ТЕМЕЉ ЗА ИЗУЧАВАЮЕ ИСТОРИЈЕ}

Историја је у групи оних друштвених наука чији су научни резултати од најдиректнијег значаја за живот савременог човека, а примарни задатак наставе историје јесте оспособљавање ученика да схвате историјске појаве и процесе, изграђујући систем знања које је применљиво и креативно (Ђукић 2008). Историјски догађаји и појаве са којима се у раном школском узрасту упознају ученици, дешавају се у времену и простору. Представе које деца о њима формирају производ су дугог развоја. Чини се разумним претпоставити да се појам прошлости код деце почиње развијати у вези са слушањем прича и бајки. Кроз причања одраслих о догађајима који за децу нису временски блиски, успоставља се зависност између прошлости и садашњости. Дакле, први појмови детета о прошлости формирају се путем непосредног чулног опажања. Карактеришу их својства генерализације и апстракције, као и недовољна издиференцираност. Тако на пример, дечији израз „давно“ није само примена за неки одређени догађај из прошлости, већ и за низ разних дешавања, карактеристичних по томе што се нису десили „сада““, ни скоро, него „много раније“. Историјска прошлост за 
децу представља неподељено знање о времену, које је неодређено далеко, неодређено дуго траје, али је основа за даљу изградњу читавог система историјских појмова.

У оквиру предмета Свет око нас и Природа и друштво концентрисане су програмске целине о прошлости током којих ученик развија одређене историјске појмове. Аутори их дефинишу као мисаоне творевине које садрже суштинска обележја и везе између предмета и појава везаних за дешавања у прошлости - формирају се на основу представа до којих појединац долази различитим мисаоним операцијама, а усвајају препознавањем познатог феномена у новим појавним облицима (БешлинШимуновић 2001, De Zan 2001, Ђуровић 2010, Кољанин 2008, Перовић 2001). Професор Димић ће рећи:

„Из мноштва дефиниција које нуди релевантна литература, определио бих се за ону која појам дефинише као замисао. Замисао која настоји да схвати и изрази шта неки историјски догађај, појава или процес по својој суштини значи и представља. Замисао пре свега због тога јер оно што подразумевамо под историјом више није постојеће и треба га, на основу трагова прошлости - материјалних, писаних и усмених историјских извора, мисаоно обликовати, оживотворити у свести и, евентуално, материјализовати у исказу о прошлости“ (Димић 2008: 9).

Схваћени као замисао о прошлости, историјски појмови омогућавају да историја прерасте просто искуство ранијих генерација, материјални остатак некадашњег човековог делања, запис, сећање, сирова грађа која доноси само мноштво појединачних података о прошлости - и прерастајући у виши облик имагинације, размишљања, повезивања, вредновања, реконструкције, уочавања - постане и део нашег живота, део садашњости (Димић 2008: 10). Мисаоно обликовање прошлости условљено је историјским раздобљима и срединама који условљавају судове, гледишта, усмерења и тиме снажно утичу на поимање прошлости и формирање мишљења о њој. Ставови које ученик формира у породици, утицаји школског окружења, убеђења која намеће социјална средина, искуства која доноси свакодневни живот - цео друштвени свет поприма различита значења у контексту времена и простора у коме се одвија. Зато кажемо да историјски појмови доживљавају сталну промену, проузроковану свакодневним повећањем садржајног обима и продубљивањем значења.

Свака прича о прошлости - свака замисао прошле стварности, мора обухватити три одреднице: одредницу човек, одредницу време и одредницу 
простор. У тој замисли занимају нас обележја начина живота и односи међу људима који су у одређено време живели на одређеном простору, и како, односно зашто су се та обележја мењала. Можемо рећи да замисао прошле стварности градимо одговарајући на питања шта, када, где, како и зашто су се догађаји збили. Категоријалним алаткама за тај процес историчари одређују: историјске изворе, историјско време - периодизацију, хронологију, континуитет/промену и узрочно-последичне односе међу посматраним догађајима ${ }^{1}$. Сваки од историјских појмова које ученици формирају и развијају током наставе пресеца се кроз ове тачке. На пример: породица, празници, прошлост, домовина, значајни датуми, историјске личности, држава, народ, рат, револуција - сваки од ових феномена контекстуализује се у одређено историјско време, посматра се кроз хронологију, промене и утврђене узрочно-последичне везе. Дакле, сазнања која се односе на далеку прошлост у настави посматрају се кроз садржаје усмерене на личну и породичну прошлост, кроз причу о развоју свога града, развојну причу о завичају и држави, о животу деце у прошлом и садашњем времену ${ }^{2}$.

Новија методичка разматрања о приступима обради историјских садржаја фокусирају се на усклађивање начина организације и извођења наставе са психофизичким могућностима ученика, то јест, ка методичкој страни предмета. Аутори истичу да се услед нагомилавања историјске грађе тежиште историје као школског предмета мора померати ка стратегијама поучавања (Кољанин 2008), док је за увођење ученика у поимање прошлости на раном школском узрасту веома важно привући њихову пажњу. У релевантној литератури помиње се ефекат истакнутости садржаја (fon Restorf efekat, према: Плут 2003), по коме се боље памте информације које су на неки начин истакнуте. На пример, ако се градиво које ће се учити на часу представи кроз садржај приче у сликама, односно изложи комбинацијом цртежа и кратког текста у виду стрипа, одговорићемо како на индивидуалне разлике међу ученицима тако и на њихове различите стилове учења. У

1 А. Пешикан је у пројекту Психолошки приступ активном учењу историје на основношколском нивоу издвојила наведене категорије. „Они не представљају конкретне чињенице, иако се преко њих исказују, већ методологију рада са тим чињеницама и сложене интелектуалне процесе који се тичу апстрактних феномена који леже иза тих појмова“ (Пешикан 2003: 55).

2 У програмима предмета Свет око нас и Природа и друштво први историјски садржаји идентификују се у оквиру обраде пригодних тема као што су: Значајне личности, Историјски споменици у мом крају и слично. Ученике млађег школског узраста са догађајима из далеке прошлости можемо упознавати и на основу уметничких приказа: историјских слика (уметничка дела, ликовне репродукције, уметничке фотографије) и развојних тема (Моја породица некад и сад, Развој места, далека прошлост домовине и друге). 
таквом контексту, стрип се може посматрати и као примарни извор - такозвани ресурс за учење, који у настави треба искористити за успостављање комуникације са градивом. Л. Андерсон (2013) дефинише ресурсе за учење као алатке које омогућавају или подржавају наставни процес - они су носиоци и посредници информација, средства комуникације, објекти и/или стимулуси у процесу учења. Опсег им се креће од говорних карактеристика, вокалних квалитета, фацијалних израза и гестова, до материјала и опреме, а за ученике су корисни јер могу да повећају разумевање садржаја, побуде заинтересованост, повећају мотивацију и допринесу позитивним ставовима ученика према садржајима који се уче. Аутори такође указују на потребу да се у савременој настави учи уз помоћ више медија који се међусобно допуњују, у чему препознајемо оправданост нашег залагања за укључивање стрипа у наставу историјских садржаја. Теоријско утемељење је когнитивно-афективна теорија учења са медијима, коју су крајем 20. века први установили Мајер и Морено, и у којој се истиче да управо мултимедија подржава начин на који људски мозак учи (Sorden 2005), као и теорија о способности радне меморије за двоструко процесуирање, по којој се информације задржавају у дуготрајном памћењу у два облика: визуелном и вербалном. Информације које су у радној меморији репрезентоване и визуелно и вербално омогућавају боље памћење (Sorden 2005: 271), док њихова синхронизација ефикасније подстиче конструкцију историјског знања и повећава ситуационо интересовање, привлачећи ефекат неке активности у току процеса учења на појединца (Chen, Darst and Pangrazi 2001). Ако знамо да дете мисли и изражава се најчешће у сликама, онда визуални и наративни спој присутан у стрипу можемо с правом посматрати као значајан подстицај за брже и лакше усвајање наставних садржаја.

Док је традиционални наставни приступ усвајања градива о далекој прошлости подразумевао њихово познавање на нивоу репродукције (меморисање чињеница) и ученика стављао у пасивну позицију посматрача, данас се говори о развоју вештина трагања, промишљања и контекстуализације разних историјских извора (Кољанин 2008). Констатација да је упоредо са променама у модерном друштву дошло и до промена у научним дисциплинама, у историји је довела до помака од велике прошлости према културној историји и микроисторији, где се ,...нагласак не ставља више на фактографију, колико на описе контекста и емоција и у којима је знанствена анализа повијесног извора попраћена инспирацијом, емпатијом и разумјевањем“ (Miklošević 2010: 208). Резултати спроведеног истраживања у коме наставни садржаји нису обликовани као типичне лекције, него су током процеса учења и поучавања сликом и музиком под- 
стицани посебни емотивни доживљаји код ученика, (расположење, емпатија и родољубље), показали су да се на овај начин успешније доприноси разумевању градива о прошлости и развоју историјских појмова (Трбојевић и сар. 2015). Наведено дозвољава констатацију да савремени методички приступи историјским садржајима апострофирају такве наставне поступке, технике и начине рада који ће ученике подстицати и мотивисати да проучавају историјске изворе, промишљају их и на основу историјске грађе закључују о давно прошлом времену. Један од могућих приступа обради градива о далекој прошлости јесте стрип. Синергија његових сликовних садржаја и једноставност текстуалних исказа стрип одавно чини моћним едукативним средством. И поред тога, општи је утисак да је у школској пракси и данас (неоправдано) занемарен.

\section{3. СТРИП У РАЗРЕДНОЈ НАСТАВИ}

Стрип је добио име по енглеској речи stripe, која дословно преведена значи трака, каиш, врпца, и односи се на низ цртежа којим се приказује одређена прича, минимално пропраћена текстом. Првобитно се појавио у дневним новинама, а онда је мало по мало стицао светску популарност и прешао у облик масовног медија ${ }^{3}$, чији суперјунаци и данас одушевљавају читаоце свих узраста.

Када је у питању терминолошко одређење, постоје многе дефиниције стрипа и оне се већ неколико деценија утврђују, мењају и допуњују, а о некима се чак изнова расправља. У првим дефиницијама као пресудна карактеристика стрипа истицано је јединство речи и слике. Дејвид Кунцл, професор историје уметности и аутор књиге The History of the Comic Strip (Историја cmpuna) дефинисао је стрип као низ засебних слика које се појављују у масовним медијима чија је оригинална намена штампани облик, с нагласком на слику, не текст, и које причају моралну и смислену причуํ. У каснијим дефиницијама стрип се одређује као низ слика у намерном низу $^{5}$, с интенцијом преноса информација које изазивају естетске реакције

3 Јуна 1938. године, када је лансиран часопис Action Comics и први пут представљен Cynермен, започиње златно доба индустрије стрипа (прим. аут.).

4 David Kunzle, The Early Comic Strips: Narrative Strips and Picture Stories in the European Broadsheet from c. 1450 to 1825, University of California Press, 1973.

5 Тако, на пример, Мартин Баркер у својој студији одређује стрип као серију узастопних слика/секвенци које причају неку причу (слика мирује, али приказује покретну секвенцу - зато је нужно уочити везу међу сликама, њихов редослед и међусобни однос - графички медиј, наративни карактер); стрип-јунаке види као релативно предвидљиве ликове чија карактеризација 
код читалаца, те опредељујући аспект постаје јединство литерарног и естетског ${ }^{6}$.

Са историјског аспекта, настанак стрипа се сагледава од времена рађања уметности и писма. Зато су неки теоретичари на становишту да корени родословног стабла стрипа продиру све до самог настанка људске цивилизације, те његовим претечом сматрају стриповане секвенце у пећинској уметности - преко Трајановог стуба ${ }^{7}$, па до такозване Таписерије из Бајеа (Драгомировић 2014). Са друге стране, стрип се данас чешће посматра у масмедијској димензији и дефинише као производ модерне цивилизације, те се његово порекло тражи искључиво у оквирима развоја штампарства $^{8}$ и појави првих високотиражних листова ${ }^{9}$ (Драгинчић и Зупан 1986). Као вербално-визуални начин уметничког изражавања, стрип се реферише и као „девета уметност“ која је кроз историју мењала више облика: народна графика, фреска, житијна икона, новински стрип, стриповне свеске и албуми, мурали и веб-стрип. Данас се у земљама као што су Француска, Италија, САД, Јапан, Србија и друге земље бивше Југославије, третира као висока уметничка форма и изучава на академском нивоу ${ }^{10}$.

одговара жанру који лик представља; док форму стрипа препознаје кроз одређени број остварених конвенција (балончићи, квадрати, ред читања) у којима варира велики број значења. По овом аутору, стрип има свој историјски контекст, на чијем почетку се карактерисао као неозбиљни, безопасни, смешни (comic strip - шаљива трака), тривијални медиј и “ниска уметност" (Barker, M. Comics: Ideology, Power, and the Critics, Manchester University Press, 1989).

6 Стрип почиње да се схвата све озбиљније, те настају: art comix стрипови (базирани на визуалним ефектима - експериментише се слагањем панела, бојама, ефектима цртања, с циљем истицања естетске вредности, док су наративна својства намерно занемарена), затим graphic novels (цртани романи), као и literary comics (литерарни стрипови) - тематика им је фокусирана на „human interest story“, приче о реалним људским судбинама (према: Милета, 2009).

7 Трајанов стуб у Риму, на коме је уклесан низ слика које приказују победоносни рат против Дачана. Сличне творевине су пронађене и у Старој Грчкој и Старом Египту, у хијероглифима и на таписеријама (Видети на адреси: http://www.vreme.co.rs/cms/view.php?id=1202760).

8 Мисли се на развој новог система литографије Алојза Зенефелдера (Alois Senefelder, 1796), прим. аут.

9 Првим модерним стриповима сматрају се Жути дечак (Yellow Kid) Ричарда Ауткалта (објављиван у New York World Џозефа Пулицера од 1895. године), као и Бил и Бул (Katzenjammer Kids) Рудолфа Диркса (почео да излази две године касније у часопису New York Journal). У нашој земљи стрип почиње да се појављује у хумористичким и забавним листовима: Месечар (Јован Јовановић, Димитрије Михајловић), Комараи (Драгутин Кесерић), Стармали (Јован Јовановић), Извор: Драгинчић, С., Зупан, 3., 1986. Историја југословенског стрипа 1. Нови Сад: Форум.

10 У Србији се стрип данас проучава у оквиру примењене графике на Факултету примењених уметности у Београду, у оквиру опште сценаристике на Факултету драмских уметности у Београду, а постоји и неколико школа стрипа (прим. аут.). 
Стрип који одликује забавно-дидактичка улога утемељио је у другој половини 19. века Невен, чика Јовин лист ${ }^{11}$, док је рађање Политике за деиу $y^{12}$, назначило нову страницу историје прича у сликама у нашој земљи. Крајем четрдесетих година 20. века код нас су се појавила прва оригинална стрип-дела ${ }^{13}$, а затим и свакако најеминентније стрип издање: Политикин забавник (први број изашао 1939, затим привремено престао са излажењем 1941, обновљен 1952, а излази и данас, прослављајући 77. годишњицу). Педесетих година прошлог века отворили су се нови приступи, нове идеје и нова истраживања у уметности стрипа, који су до краја осамдесетих променили слику стрип-сцене у нашој земљи поставивши је на значајно високо место, које у новој друштвеној клими с почетка 20. века преузима млађа генерација стрип аутора, истрајавајући у особеном стварању чаролија које носе приче у сликама.

Дуго су стрипови под клупом представљали симбол одрастања и ученички бунт против школских канона. Иако је снажна експанзија интерфејса знатно умањила његову моћ, као уосталом и моћ књиге, и читања уопште; најновија истраживања показују да скоро сва деца основношколског и средњошколског узраста данас поново радо читају стрипове (Chalkiadaki 2009, Lazzarich и Томљеновић 2011, Тадић 2007). Схваћен као визуелно приповедање, односно својеврстан спој нарације и призора, у коме се помоћу врло мало текста и низа цртежа приказује одређени догађај, стрип за ученике може бити вишеструко подстицајан: делује стимулативно, развија способност посматрања, увиђања појединости и пружа могућност замишљања ситуације у којој се збива радња (Петровачки и Савић 2012). Неки методичари чак сматрају да са плански одабраним стрипом наставник не може „промашити“ јер се стриповима деца одају без икаквог наговарања.

Стрип се вешто може уклопити у рад на часу на коме се обрађују друштвени садржаји. Стриповни предложак применљив је у свим фазама часа Свет око нас/Природа и друштво. У уводном делу он може бити значајно мотивационо средство и покретач размишљања о одређеној теми

11 Невен - часопис Јована Јовановића Змаја, први број изашао јануара 1880, престао да излази крајем новембра 1908. године (прим. аут.).

12 16. јануара 1930. године београдски дневни лист Политика као додатак објављује прву стрип-шалу, а затим су уследиле стриповане биографије: Растка Немањића, Карађорђа, Доситеја Обрадовића и др. У стрипу „Дрски обијач и Храбри Перица“ (објављеном у 31. броју) примењен је најкарактеристичнији облик текстуалне комуникације - облачићи/филактери (прим. аут.).

13 Мисли се на стрип аутора Власте Белкића, а затим и стрипове аутора у часописима Мика Миш и Микијево ичарство (прим. аут.). 
- питању које hе на часу бити разматрано. Стрипом, такође, можемо презентовати проблемску ситуацију или изложити главне информације које ученик треба да запамти. Ученицима можемо задати да на договорену тему сами ураде стрип на часовима утврђивања градива или код куће као домаћи задатак. Пример употребе стрипа током лекција о картографском описмењавању конкретизован је у објашњењу појма географска карта ( Тадић 2007: 211), који је представљен на слици 1.

\section{Слика број 1: Географска карта}
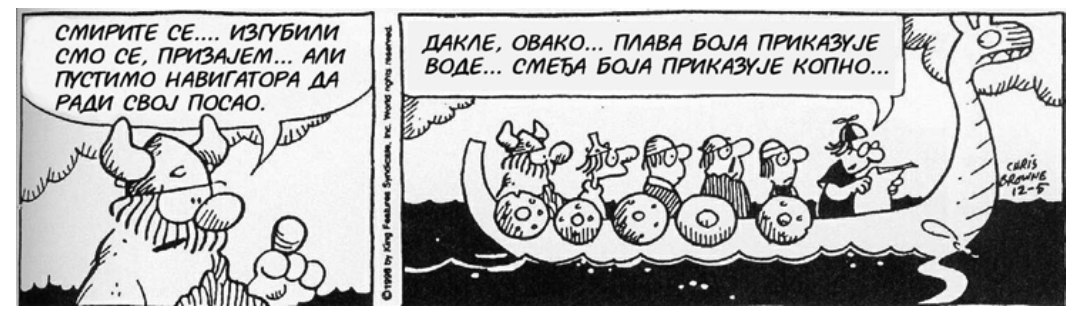

Слика 6. Географска карта. Да 6 и је користили на терену, карту треба оријентисати, тј. поставити је тако да 6 очна ивица рама буде ус мерена тачно према северу Данас север одређујемо помоћу компаса или GPS уређаја, а некада, када тих помагала није било, север је одређиван само астрономским методама. Посебно је вештина оријентације 6 ила цењена код морепловаца - на отвореном мору обала се не види и нема никаквих оријентира. Зато су спасоносне оријентире морепловци потражили на небеском своду: Сунце дању, а Месец, звезде, сазвежђа и звездане кон фигурације, ноћу.

У основним школама Црне Горе спроводи се пројекат „Дјецо, пишите Омбудсману“, с циљем да се ученици упознају с инситуцијом заштитника и заштитом сопствених права. У првој фази пројекта деца су се одазивала на позив да пишу Омбудсману о свим ситуацијама у којима сматрају да су угрожена или прекршена дечја права, а онда су у другој фази, на основу дечјих писама, изабране теме за израду стрипа: вршњачко насиље; насилно, увредљиво и друго непримерено понашање наставника према ученицима; дискриминација; недовољно учешће деце у доношењу одлука које их се тичу; и насиље у породици. Тако је 2013. Завод за уџбенике и наставна средства у Подгорици први објавио стрип као наставно средство, издање Невоље са Рокијем и друге приче о дјечјим правима. Издато је као додатак уџбенику за грађанско васпитање ${ }^{14}$.

14 Видети на адреси: http:/www.vijesti.me/vijesti/strip-kao-pomocno-nastavno-sredstvo-unastavi-gradanskog-obrazovanja-849283 Посећено: 13. 2. 2016. 
Слика број 2: Страница стрипа Невоље са Рокијем и друге приче о дјечјим правима

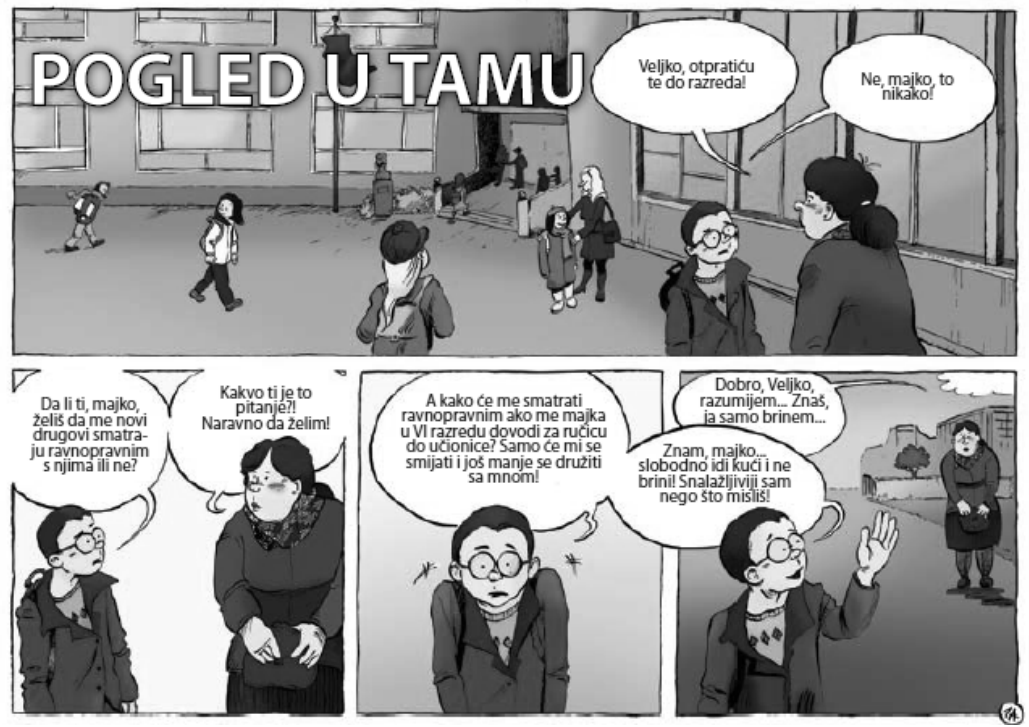

\section{4. СТРИПОВНИ ПРЕДЛОЖАК У ОБРАДИ ИСТОРИЈСКИХ САДРЖАЈА}

Структура наставних програма за предмете Свет око нас/Природа $u$ друштво $^{15}$ који се изучавају у нижим разредима основне школе у Србији, јасно указује на континуитет у развијању знања у изучавању прошлости. Први историјски садржаји ученицима се презентују у оквиру обраде $п р и$ годних тема (Празници, Значајне личности, Историјски споменици у мом крају и сл.) и развојних тема (Моја породица некад и сад, Развој места, далека прошлост домовине и др.). У програмима Природе и друштва (трећи разред) садржаји блиски историји идентификују се у теми Кретање y простору и времену - обрађују се временске одреднице (датум, година, деценија, век), ближа и даља прошлост, а целокупна тема Наше наслеђе упознаје ученике са деловима: Како откривамо прошлост (сведоци ближе и даље прошлости), Трагови прошлости - материјални, писани, усмени и

15 У првом и другом разреду ученици изучавају садржаје интегрисаног предмета Свет око нас, док се предмет у трећем и четвртом разреду назива Природа $и$ друштво (прим. аут.). 
обичајни, Чувамо и негујемо остатке прошлости. У програмској теми Некад u cad садржане су целине Одређивање ближе и даље прошлости (живот у породици, школи, насељу, завичају), Мој завичај и његова прошлост - културна и историјска (начин живота, производња и размена добара, занимања, одевање, исхрана, традиционалне светковине, игре, забава...), Ликови из наших народних песама, приповетки и бајки - повезаност догађаја из прошлости са местом и временом догађања, Знаменити људи нашег краја (просветитељи, песници, писци, сликари, научници).

За четврти разред централна тематска целина која се бави прошлошћу јесте Осврт уназад - прошлост, са следећим насловима: Трагови прошлости (пратити трагове прошлости: своје и своје породице, насеља-краја у коме живим), Временска лента (временски одредити векове, констатовати неке типичне карактеристике векова), Лоцирање догађаја-датума (сналазити се на временској ленти: лоцирати догађаје, датуме; одредити време, животно доба својих родитеља и њихових предака; одредити неке познате савременике из истих и различитих области као и претходнике и следбенике из истих области), Хронологија различитих научних открића, Начин живота у средњем веку (информисати се о различитим животним ситуацијама људи у средњем веку на територији Србије: село-град, живот некад и сад), Прошлост српског народа (упознати се са значајним догађајима из националне прошлости: сеобе Срба, простор на коме су Срби живели), Први и Други српски устанак (стварање што објективније слике о догађајима из прошлости коришћењем различитих историјских извора, на временској ленти хронолошки одредити развој - континуитет и дисконтинуитет државе Србије, упознати се са њеним владарима, почев од лозе Немањића па све до данас), Први и Други светски рат (уочити везу између историјских збивања у свету и код нас $)^{16}$.

Стрип може бити вишеструко инспиративан у раду са наведеним историјским садржајима. Као временски и просторно веома далеки од емпиријског искуства на основу кога се у млађем школском добу формирају појмови, историјски садржаји су ученицима веома тешки за усвајање. Будући да у овом узрасном добу дете мисли и изражава се најчешће у сликама (Lazzarich и Томљеновић 2011), управо стрип постаје пријемчива

16 Тематске целине и наставне јединице наведене су из Правилника о наставном плану за први, други, трећи и четврти разред основног образовања и васпитања и наставном програму за трећи разред основног образовања и васпитања. Просветни гласник РС, бр. 1/05, $15 / 06$ и 2/08, и Правилника о наставном програму за четврти разред основног образовања и васпитања. Службени гласник РС, Просветни гласник, 3/2006. 
изражајна форма да ђацима приближимо историјско време, догађаје и личности које су у њима учествовали.

Два велика уметника, Жак Тарди и Жан Пјер Верне ${ }^{17}$ су на врло занимљив начин наративно и визуално осликали страхоте Првог светског рата. Проклети рат је велика, сугестивна и емотивна прича у стрипу која Велики рат сагледава са аспекта обичних људи, војника и страдалника којима је он донео само једно - велику трагедију. Ево секвенци које могу послужити у обради теме Први светски рат (четврти разред).

\section{Слика број 3: Странице стрипа Проклети рат}
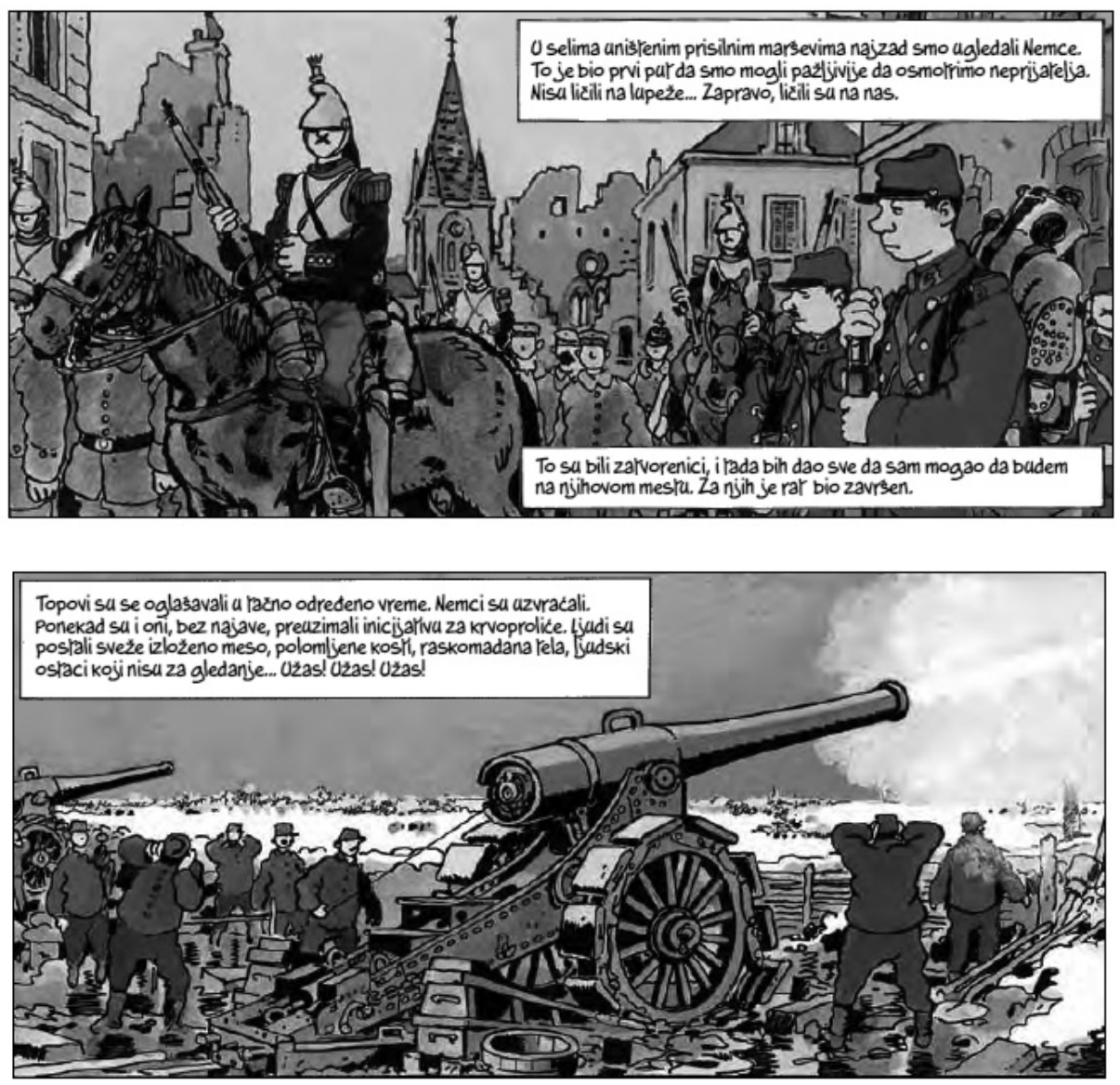

17 Tardi, Ž. Verne, Ž. (2013). Prokleti rat 1914-1915-1916. Beograd: Darkwood. 
Након представљања ових слика, са ученицима разговарамо о садржају: упозоравамо на текст у првом лицу једнине, који сугерише лични доживљај. Наратор представља супротну страну и каже: „Нису личили на лупеже... Заправо, личили су на нас“. Дакле, са ученицима разматрамо да је рат оружани сукоб између држава, али да су његови актери обични људи, који увек подносе највеће жртве. На следећој слици управо је истакнуто да је рат страдање у коме војници жртвују највредније: живот. „Немци су узвраћали... Људи су постали свеже изложено месо, поломљене кости, раскомадана тела, људски остаци који нису за гледање... Ужас! Ужас! Ужас!“ Доживљај историјског времена ученици преносе на лични план, док наставникова нарација треба да помогне у постављању историјског догађаја у контекст - разумевање Првог светског рата који је део националне прошлости, али исто тако и део прошлости других народа и држава.

Слике стрипа могу даље послужити за наставак теме, у којој ће се разговарати о Србији у Великом рату - њеном учешћу у оружаним борбама, војним победама и поразима, али и огромном страдању обичних људи, жена, деце и стараца, који су Србију обележили као убедљиво највећу жртву од свих земаља учесница. Ученицима можемо понудити да сачине неколико каишева стрипа којим ће изразити своје разумевање наставног садржаја. Ако наставник има афинитета, могао би он да понуди почетне стрип-слике којима би подстакао ученике на продукцију - било да свако на папиру добије исте сличице и самостално заврши каиш стрипа, или да се определи за неколико различитих слика, које ће ученици наставити током групног рада. Могући варијетети су и постављање слика за које наставник оставља празне облачиће, а ученици имају задатак да их попуне - односно да у складу са оним што су научили поставе вербални исказ. У сваком случају, израђујући свој, или допуњујући већ започети стрип, ученици ће исказивати научено и испољавати доживљене емоције, и тиме показати колико и како су разумели наставне садржаје.

\section{Пример употребе стрипа за тему Знаменийи љуgи нащей краја}

За пример како бисмо стрип могли укључити у наставу у којој се обрађују историјски садржаји, изабрали смо наставну тему Знаменити људи нашег краја (програм предмета Природа и друштво, трећи разред). Циљ теме је да се укаже на различите трагове који нас воде у прошлост завичаја, а први је упознавање са личностима које су обележиле прошлост места у коме се живи. Следећи те трагове по пажљиво осмишљеној сликовној причи, ученицима се омогућује да на нов, оригиналан и забаван начин упознају 
своје културно наслеђе. Предлажемо да се настава организује у форми двочаса, са следећим етапама:

1. мотивациона: ученици посматрају краћи документарни филм о прошлости Сомбора, у коме су назначене неке од знаменитих личности о којима ће се касније говорити;

2. разговор о утисцима - са ученицима отварамо проблемска питања: ко су биле значајне личности (у науци, култури, спорту, здравству и др.) које су својим радом оставиле траг у прошлости Сомбора;

3. најава циља часа - приказом стрипа упознајемо значајне личности нашег места и њихове задужбине које су оставили за будућност;

4. презентација стриповне приче у фронталном раду;

5. обједињавање усвојених сазнања у групном раду: ученици пишу кратак новински извештај о одређеној знаменитој личности - као репортери који су на основу доступних извора оформили слику прошлости.

Припрема наставника за овакав час изузетно је комплексна, јер осим пажљивог упознавања и избора историјске грађе која ће чинити наставни садржај, он мора познавати одлике стриповног медија, али и поседовати склоност ка њему. Стриповна прича коју представљамо осмишљена је током практичног испитног рада студената Педагошког факултета у сомборским школама-вежбаоницама ${ }^{18}$. Идеја је да се значајне личности града сретну на сомборској калдрми у једном замишљеном „заједничком“ дану. Главни актер стрипа је истакнути сомборски новинар, хроничар и завичајни историчар - Миленко Бељански. Он ученике упознаје са најславнијим грађанима Сомбора: Аврамом Мразовићем (1756-1826), оснивачем прве школе за образовање учитеља словенског живља под називом Норма; Николом Вукићевић (1830-1910), педагогом, писцем, наставником и управником Српске учитељске школе (Препарандија); Вељком Петровићем (1884-1967), књижевником и Карлом Бјелицким (1813-1878), оснивачем градске библиотеке, али и многим другим: Ернест Бошњак (оснивач кинематографије у нашој земњи), Чихаш Бене (градоначелник Сомбора с краја 19. века који је озеленео град и околину), Петар Коњовић (композитор), Милан Коњовић (сликар).

18 Уз ментрорство аутора, стрип је осмислила и час Природе и друштва реализовала: Ана Милош, студенткиња четврте године Педагошког факултета у Сомбору (прим. аут.). 
Слика 4: Избор каишева стрипа Значајне личности Сомбора: сусрет великана кроз историјско време
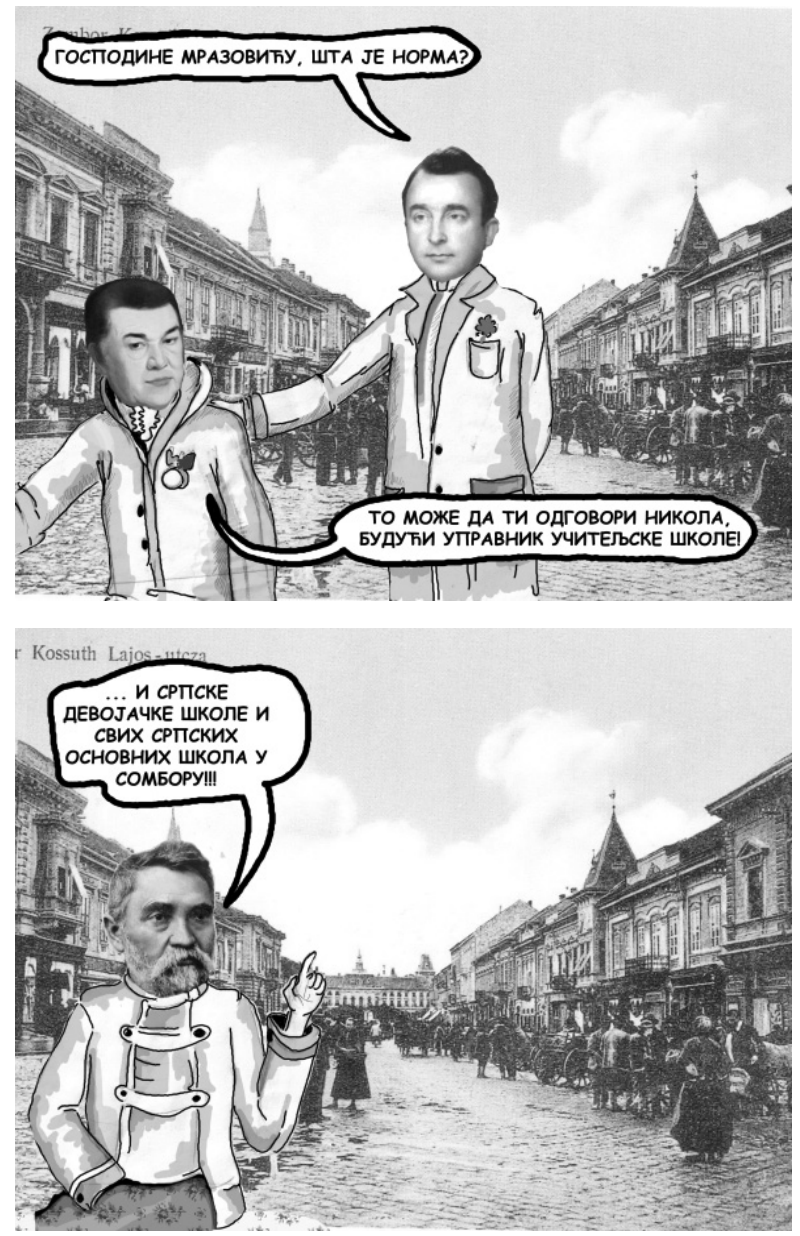

На почетку ученике упознајемо са новинарем Миленком Бељанским, који их води кроз стрип. Прве личности говоре о Норми.

Шетајући градом, чика Миленко у партији шаха сусреће Карла Бјелицког и Лазу Костића (партију посматра рвач, први сомборски олимпијац, Стеван Пишта Нађ). Са ученицима се разговара о настанку сомборске библиотеке, а онда им скрећемо пажњу на облачић стрипа у коме песник смишља стихове за Santa Maria della Salute. 

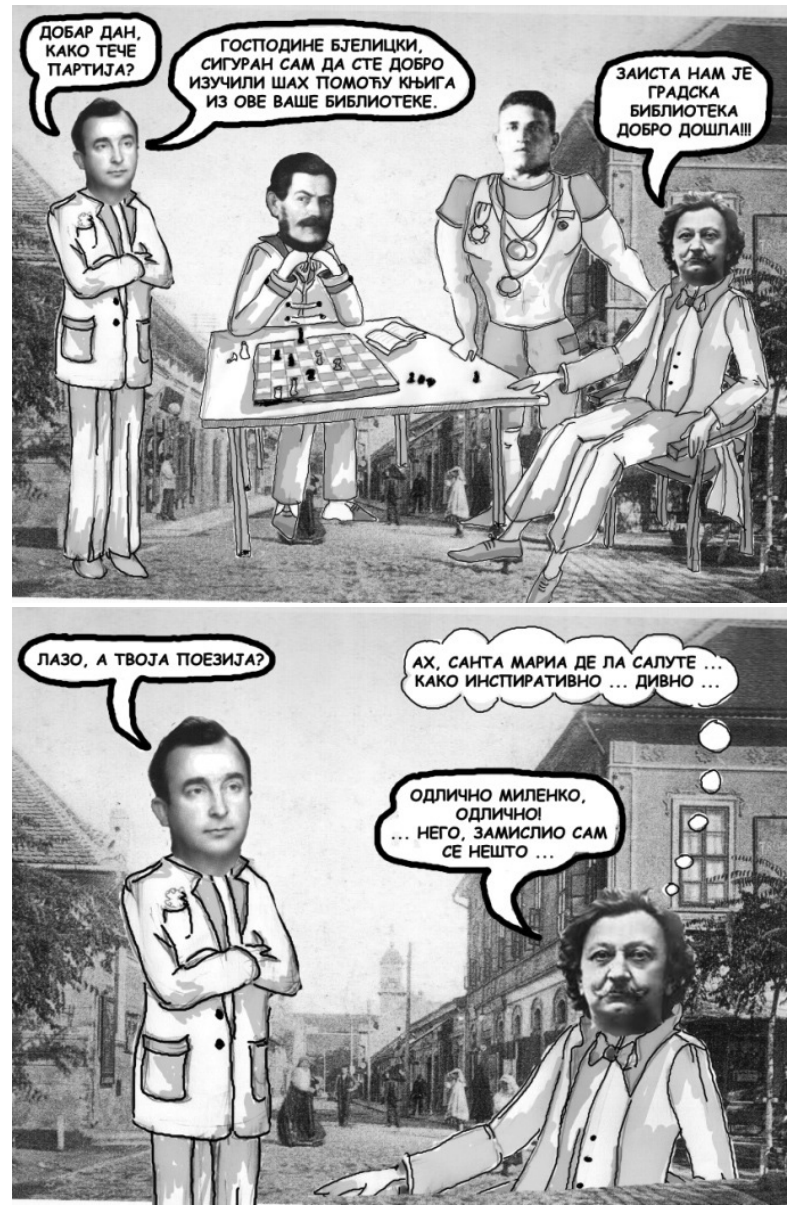

Шетњу улицама града чика Миленко завршава у парку: ту сусреће градоначелника који сади прве бођоше - у нади да ће њихова лековита својства допринети здрављу суграђана. Садњу ће за историју овековечити Ернест Бошњак. Стриповна прича приводи се крају у згради Музичке школе, где ученике упознајемо са уметничким радом Петра Коњовића и Милана Коњовића. 

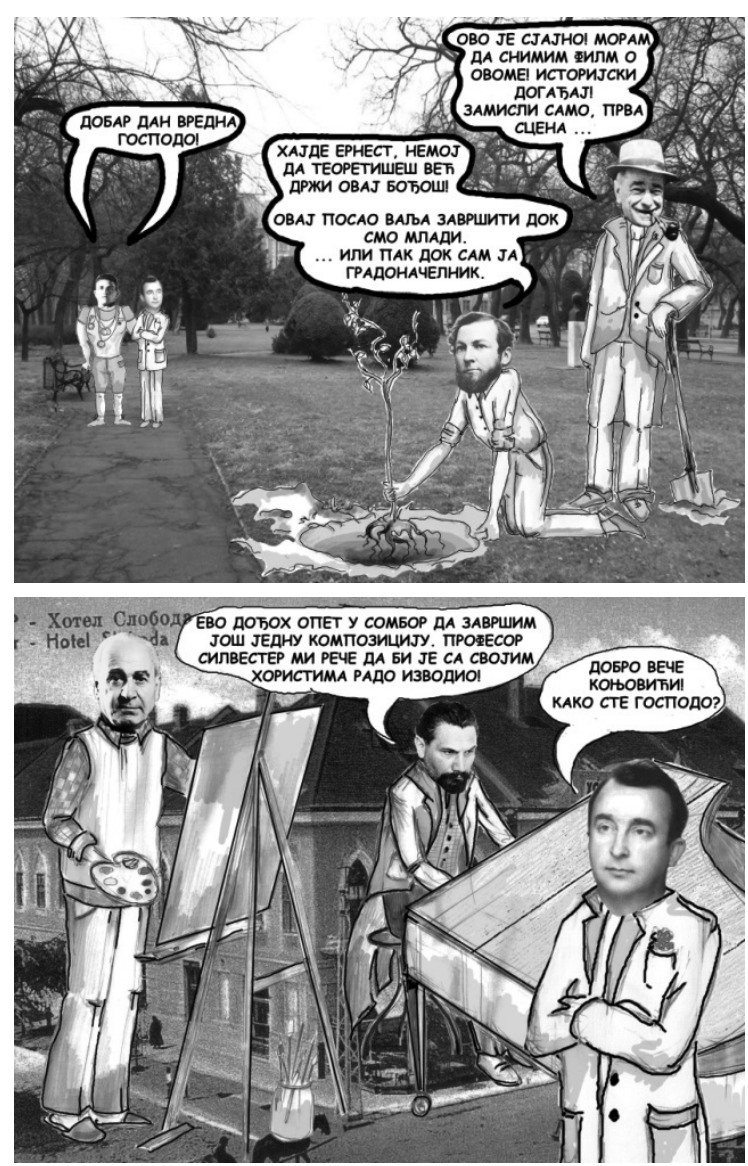

Свака слика стрипа са ученицима се анализира у фронталном раду: разговара се о историјском времену у коме је одређена личност живела, о делима по којима ћемо је памтити, и износе се најупечатљивији моменти из њихових живота. Ученици активно учествују у презентовању садржаја, и позивају се да и они истраже занимљиве моменте из живота поменутих личности. На тај начин ученици конструишу целовиту слику живота у прошлости, односно обликују слику завичајне историје: „Знања и вештине које у таквом раду ученици стичу повезују идеје науке и свакодневни живот, те доприносе усвајању, преношењу и примени сазнања на целовит и смислен начин“ (Шпановић и Трбојевић 2013: 42). Истакнутим примером показује се да употреба стрипа у настави може допринети да и ученици млађег школског узраста успешно уче о завичајној прошлости и реконструишу дух одређене историјске епохе. 


\section{ЗАКЉУЧАК}

Иако се историја као наставни предмет уводи у петом разреду основне школе, многи историјски садржаји присутни су у сва четири млађа разреда. Такви садржаји су у традиционалној настави за ученике апстрактни и тешко схватљиви, те су неопходне промене које би се одразиле на функционално и квалитативно повезивање циљева, садржаја и метода рада, избора наставних средстава и извора сазнања у настави. Новија методичка разматрања о историјским садржајима у настави фокусирају се на усклађивању начина организације и извођења наставе са психофизичким могућностима ученика, то јест, ка методичкој страни предмета. То значи да је током реализовања наставних садржаја у предмету Природа и друштво, а посебно током обраде градива о далекој прошлости, потребно примењивати модалитете активног укључивања ученика у наставни процес. Оно се одражава у овладавању активностима (историјско истраживање, интерпретација доказа, примена претходно наученог и др.) и развијању оних способности мишљења које су алати за рад са историјским садржајима: поређење, класификовање, анализирање, предвиђање, закључивање и др. Крајњи циљ је да у процесу подстицања ученика да кроз димензију прошлости (како су настајали) и садашњости (како их развијамо) разумеју историјске феномене и обликују свој културни идентитет.

У подстицању ученика на замисао о прошлој стварности (Димић 2008, Ђуровић 2010), определили смо се за стрип. Формом која синхронизује сликовни и знаковни систем порука, стрип отвара пут непосредне комуникације ученика са градивом које се учи, а наклоност према причама у слици коју деца имају омогућава ефикасније упознавање са историјским садржајима. У апликативном делу указали смо на могућности употребе стрипа у обради теме Први светски рат (Природа и друштво, четврти разред), и представили модел стриповног предлошка за лекцију Знаменити људи нашег краја (Природа и друштво, трећи разред). Традиционално пријемчљив и радо читан, стрип поседује и многе друге предности у односу на класично излагање наставног градива: визуално је атрактиван па мотивише ученике; једноставно посредује између ученика и садржаја, те ствара позитивну комуникацију; може бити полазиште за отварање проблемских ситуација и даља истраживања историјских извора; и помаже у анализи и синтези захтевнијих наставних тема. Зато његова употреба у настави у којој се излажу историјски садржаји може значајно допринети успешном усвајању знања и укупним ученичким постигнућима у школи. 


\section{ЛИТЕРАТУРА:}

Anderson, L. (ed.) (2013). Teaching for Learning. Beograd: CDRSEE.

Barker, M. (1989). Comics: Ideology, Power, and the Critics. Manchester University Press.

Chalkiadaki, A. (2009). "Fun and Effectiveness in the School Class". Odgojne znanosti, 17: 87-102.

Chen, A., Darst, P. W., Pangrazi, R. P. (2001). “An exemination of situational interest and its sources". British Journal of Educational Psychology vol, 71: 383-400.

De Zan, I. (2001). Metodika nastave Prirode i društva. Zagreb: Školska knjiga.

Димић, Љ. (2008). “Листа кључних знања за крај основног образовања за наставни предмет Историја“, у Историја - кључни појмови за крај обавезног образовања: приручник за наставнике, ур. А. Ђуровић (Београд: Завод за вредновање квалитета образовања и васпитања): 9-14. [Dimić, LJ. (2008). "Lista ključnih znanja za kraj osnovnog obrazovanja za nastavni predmet Istorija“, u Istorija - ključni pojmovi za kraj obaveznog obrazovanja: priručnik za nastavnike, ur. A. Đurović (Beograd: Zavod za vrednovanje kvaliteta obrazovanja i vaspitanja): 9-14.]

Драгинчић, С., Зупан, 3. (1986). Историја југословенског стрипа 1. Нови Сад: Форум. [Draginčić, S., Zupan, Z. (1986). Istorija jugoslovenskog stripa 1. Novi Sad: Forum.]

Драгомировић, Н. (2014). Рат у каишевима. Приступљено: 9. 2. 2016. [Dragomirović, N. (2014). Rat u kaiševima. Pristupljeno: 9. 2. 2016.] URL: <http://www.vreme.co.rs/cms/view.php?id=1202760>

Ђукић, М. (2008). “Дидактичке основе „диференцијације“ у настави историје“, у Методички приручник из историје, uр. М. Лазић (Београд: Друштво историчара Србије „Стојан Новаковић“, Институт за савремену историју): 142-149. [Đukić, М. (2008). "Didaktičke osnove „diferencijacije“" u nastavi istorije“, u Metodički priručnik iz istorije, ur. M. Lazić (Beograd: Društvo istoričara Srbije „Stojan Novaković“", Institut za savremenu istoriju): 142-149.]

Ђуровић, А. (2010). “Свет у написаној речи - друштво у огледалу „прошле стварности“, у Кључна знаға из прошлости у наставним предметима Свет око нас и Природа и друштво као основа за учење Историје: приручник за учитеље и учитељице, ур. Видосава Граховац и др. (Београд: Завод за вредновање квалитета образовања и васпитања): 19-24. [Đurović, A. (2010). "Svet u napisanoj reči - društvo u ogledalu ,prošle stvarnosti“", u Ključna znanja iz prošlosti u nastavnim predmetima Svet oko 
nas i Priroda i društvo kao osnova za učenje Istorije: priručnik za učitelje $i$ učiteljice, ur. Vidosava Grahovac i dr. (Beograd: Zavod za vrednovanje kvaliteta obrazovanja i vaspitanja): 19-24.]

Кољанин, Д. (2008). "Историја као научна дисциплина и школски предмет“, у Историја - кључни појмови за крај обавезног образовања: приручник за наставнике, ур. А. Ђуровић (Београд: Завод за вредновање квалитета образовања и васпитања): 77-84. [Koljanin, D. (2008). "Istorija kao naučna disciplina i školski predmet", u Istorija - ključni pojmovi za kraj obaveznog obrazovanja: priručnik za nastavnike, ur. A. Đurović (Beograd: Zavod za vrednovanje kvaliteta obrazovanja i vaspitanja): 77-84.]

Kunzle, D. (1973). The Early Comic Strips: Narrative Strips and Picture Stories in the European Broadsheet from c. 1450 to 1825. University of California Press.

Lazzarich, M., Томљеновић, 3. (2011). „Могућност употребе стрипа у развоју комуникацијске компетенције“. Настава и васпитање 60(1): 5-22. [Lazzarich, M., Tomljenović, Z. (2011). „Mogućnost upotrebe stripa u razvoju komunikacijske kompetencije“. Nastava $i$ vaspitanje 60(1): 5-22.]

Милета, С. (2009). "Високо у популарном и популарни интертекст - примјер Бонелијевих стрипова“. Аутсајдерски фрагменти 1/2: 141-170. [Mileta, S. (2009). "Visoko u popularnom i popularni intertekst - primjer Bonelijevih stripova“. Autsajderski fragmenti 1/2: 141-170.]

Miklošević, Ž. (2010). "Muzeji i njihov odnos spram prošlosti“. Povijest $u$ nastavi 2: 203-215.

Obradović, S. i dr. (2013). Nevolje sa Rokijem i druge priče o dječjim pravima. Podgorica: Institucija zaštitnika ljudskih prava i sloboda Crne Gore (Ombudsman), NVO Akcija za ljudska prava, Приступљено 12. 4. 2016. URL: $<$ https://www.google.rs/webhp?sourceid=chrome-instant\&ion=1\&es $\mathrm{pv}=2 \& \mathrm{ie}=\mathrm{UTF} 8 \# \mathrm{q}=$ strip + nevolje $+\mathrm{sa}+$ rokijem $+\mathrm{i}+$ druge + pri $\% \mathrm{C} 4 \% 8 \mathrm{De}+\mathrm{o}$ + dje $\% \mathrm{C} 4 \% 8 \mathrm{Djim}+$ pravima,pdf\&start $=10>$

Перовић, М. (2001). Методика наставе историје. Београд: Завод за уџбенике и наставна средства. [Perović, М. (2001). Metodika nastave istorije. Beograd: Zavod za udžbenike i nastavna sredstva.]

Петровачки, Љ., Савић, М. (2012). “Стрип у настави граматике српског језика“. Методички видици 3: 11-28. [Petrovački, LJ., Savić, M. (2012). "Strip u nastavi gramatike srpskog jezika". Metodički vidici 3: 11-28.]

Пешикан, А. (2003). Настава и развој друштвених појмова код деце. Београд: Завод за уџбенике и наставна средства. [Pešikan, А. (2003). Nastava i razvoj društvenih pojmova kod dece. Beograd: Zavod za udžbenike i nastavna sredstva.] 
Плут, Д. (2003). Уибеник као културно-потпорни систем. Београд: Завод за уџбенике и наставна средства. [Plut, D. (2003). Udžbenik kao kulturno-potporni sistem. Beograd: Zavod za udžbenike i nastavna sredstva.]

Sorden, S. D. (2012). "The Cognitive Theory of Multimedia Learning“. (online). Приступљено 27. 2. 2016. URL.<http://www.scoop.it/.../sorden-draftmultimedia2012-pdf.>

Шимуновић-Бешлин, Б. (2001). Како се пише историја. Нови Сад: Платонеум. [Šimunović-Bešlin, B. (2001). Kako se piše istorija. Novi Sad: Platoneum.]

Тадић, М. (2007). “Стрип у настави географије“. Глобус 32: 147-152. [Tadić, M. (2007). "Strip u nastavi geografije". Globus 32: 147-152.]

Tardi, Ž. Verne, Ž. (2013). Prokleti rat 1914-1915-1916. Beograd: Darkwood. Трбојевић, А., Шпановић, С. (2013). "Интегрисана настава Природе и друштва у функцији формирања друштвених појмова“. Иноващије y настави 2: 30-44. [Trbojević, A., Španović, S. (2013). "Integrisana nastava Prirode i društva u funkciji formiranja društvenih pojmova“. Inovacije u nastavi 2: 30-44.]

Trbojević, A., Jeremić, B. and R. Pećanac (2015). “Application of Computers and Vocal Music Performance in the Formation of Social Concepts of Early School Age Children“, in Zbornik vedeckovýskumných prác, ed. Mgr. Miroslava Fudorová (Banska Bistrica: Pedagogická fakulta Univerzity Mateja Bela v Banskej Bystrici): 195-212.

\section{Остали извори:}

Правилник о наставном плану за први, други, трећи и четврти разред основног образовања и васпитања и наставном програму за трећи разред основног образовања и васпитања. Просветни гласник РС, бр. 1/05, 15/06 и 2/08. [Pravilnik o nastavnom planu za prvi, drugi, treći $i$ četvrti razred osnovnog obrazovanja i vaspitanja i nastavnom programu za treći razred osnovnog obrazovanja $i$ vaspitanja. Prosvetni glasnik RS, br. $1 / 05,15 / 06$ i $2 / 08$.]

Правилник о наставном програму за четврти разред основног образовања u васпитања. Службени гласник РС-Просветни гласник, 3/2006. [Pravilnik o nastavnom programu za četvrti razred osnovnog obrazovanja $i$ vaspitanja. Službeni glasnik RS-Prosvetni glasnik, 3/2006.] 


\section{Штампана издања:}

New York Journal 12 Decembar 1897, (William Randolph Hearst, ed): „Katzenjammer Kids“ by Rudolph Dirks. Приступљено 2. 4. 2016. URL. $<$ http://www.nysl.nysed.gov/nysnp/history.htm>

New York World 9 February 1895, (Joseph Pulitzer, ed): „Yellow Kid“ by Richard Felton Outcault. Приступљено 2. 4. 2016. URL. $<$ http://www. nysl.nysed.gov/nysnp/history.htm>

Политика - Политика за деиу 14. 8. 1930: „Дрски обијач и храбри Перица“. Приступљено 12. 2. 2016. [Politika-Politika za decu 14. 8. 1930: „Drski obijač i hrabri Perica“. Pristupljeno 12. 2. 2016.] URL.<http:// www.rastko.org.rs/strip/1/zupan-draginicic_1/ilustrovane-price_l.html $>$ 
Aleksandra Trbojević

University of Novi Sad

Faculty of Pedagogy

Sombor

aleksandrauc@pef.uns.ac.rs

\section{THE USE OF A COMIC BOOK IN PROCESSING HISTORICAL CONTENTS IN CLASSROOM TEACHING}

\section{Summary}

The paper points to a complex problem of adopting and understanding historical contents in classroom teaching and emphasizes a comic book as a possible methodical solution. In order to be able to perceive past reality it is necessary to possess concepts that enable the understanding of historical events, phenomena and processes, and as younger school-aged children have not yet mastered abstract reasoning, for them, visual perception represents an incentive to successfully create an image of the distant past. The paper emphasizes that in the synchronization of the image and the sign system of messages, a comic book, paves the road for students to directly communicate with the teaching material, and children's affection towards stories in pictures allows for a more efficient adoption of historical contents. The advantages of working with a comic book template, in relation to the traditional presentation of the teaching material, have been singled out: a comic book is visually attractive, which motivates students; a comic book mediates between the students and the contents in a very simple manner, enabling positive communication; a comic book can be a starting point for addressing problem situations and further investigation of historical sources; a comic book assists in the analysis and synthesis of the more demanding teaching topics. This is why its use in teaching in which historical contents are presented can significantly contribute to the successful adoption of knowledge and overall student achievement in schools.

In the applicative part, the possibilities of using a comic book in processing the topic of World War I (Nature and Society, fourth grade) have been presented, as well as a model of a comic book template for the lesson Famous people of our region (Nature and Society, third grade). These show that the use of a comic book in classroom teaching can help students of a younger school-age to successfully learn about their homeland past and reconstruct the spirit of a particular historical epoch.

Keywords: comic book, historical contents, teaching of Nature and Society.

Примљено: 4. 6. 2016.

Прихваћено: 15. 7. 2016. 